\title{
SEJARAH DAN PERKEMBANGAN LEMBAGA PENDIDIKAN MUHAMMADIYAH DI KABUPATEN SUMBAWA NUSA TENGGARA BARAT TAHUN 1940-2014
}

\author{
Abdul Alimun Utama \\ Dewan PCW Perhimpunan Al-Irsyad Kabupaten Nusa Tenggara Barat (NTB) \\ E-Mail: alimunutama_abdul@gmail.com
}

\begin{abstract}
Muhammadiyah organization in Sumbawa regency was established on 6 May 1940. The movement and the development of educational institutions Muhammadiyah Sumbawa has been felt by the community. The development of educational institutions Muhammadiyah Sumbawa able to set up education through three lines of education, namely: formal education, non-formal and informal. formal education has been established since the year 1941-2013, the number of 23 educational institutions, including; 4 (four) kindergarten Ortom(Autonomous organizations)Aisyiah, 6 (six) elementary and MI (madrasah ibtidaiyah) , 6 (six) SMP (junior high school)and MTS (madrasah tsanawiyah), 6 (six) SMA (Senior High School) and MA (madrasah aliyah), 1 (one) colleges. While informal pathways, include; orphanage, cottage tahfizulquran and manage mosques. As developed through informal education through a variety of program areas stewardship activities Muhammadiyah Sumbawa. Based on the above background, the formulation of the problem in this research is How the History and Development of Institutions of Muhammadiyah in Sumbawa and what are the factors supporting and inhibiting the development of Muhammadiyah Education Institute in Sumbawa. While the purpose of this study was to describe the history and development of educational institutions Muhammadiyah in Sumbawa as well as factors supporting and inhibiting. Based on the research results, indicate that during the struggle for the development of educational institutions Muhammadiyahof the year 1952-2014, Muhammadiyah Sumbawa able to give an important role in developingthe educational institutions of Muhammadiyah Sumbawaby providing of islamic guidance, which is realized by three educational paths, is education formal, non-formal and informal. As for enabling and inhibiting factors that influencesuccess of the organization Muhammadiyah Sumbawa in developing educational institutions Muhammadiyah can be seen from several internal and external factors are schools, human resources and educational tools. While the factors that most basic is a factor that is an asset fund the passage of a education, While the inhibiting factors that most basic is a factor that is an asset fund the passage of a education, and unmatched strictly by the state education agency.
\end{abstract}

Keyword: history and development of educational institutions Muhammadiyah.

Abstrak: Berdirinya organisasi Muhammadiyah di Kabupaten Sumbawa pada tanggal $6 \mathrm{Mei}$ 1940. Gerakan dan perkembangan lembaga penddikan Muhammadiyah Sumbawa telah dapat dirasakan oleh masyarakat. Perkembangan lembaga penddikan Muhammadiyah Sumbawa mampu mendirikan pendidikan melalui 3 jalur pendidikan, yaitu: pendidikan formal, nonformal dan informal. melalui jalur pendidikan formal telah didirikan dari semnjak tahun 1941-2013, dengan jumlah 23 lembaga pendidikan, meliputi; 4 (empat) jenjang TK Ortom Aisyiah, 6 (enam) jenjang SD dan MI, 6 (enam) jenjang SMP dan MTS, 6 (enam) jenjang SMA dan MA, 1 (satu) jenjang perguruan tinggi. Melalui jalur nonformal, meliputi; panti asuhan, pondok tahfizul qur'an dan mengelola masjid. Adapun melalui pendidikan informal yaitu dikembangkan melaui berbagai program kegiatan bidang-bidang kepengurusan Muhammadiyah Sumbawa. Berdasarkan latar belakang di atas, maka rumusan masalah dalam penelitian ini adalah Bagaimanakah Sejarah dan Perkembangan Lembaga Pendidikan Muhammadiyah di Kabupaten Sumbawa dan apa saja yang menjadi faktor pendukung dan penghambat perkembangan Lembaga Pendidikan Muhammadiyah di Kabupaten Sumbawa. 
Sedangkan tujuan penelitian ini adalah untuk mendeskripsikan sejarah dan perkembangan lembaga pendidikan Muhammadiyah di Kabupaten Sumbawa serta faktor pendudukung dan penghambatnya. Berdasarkan hasil penelitian, menunjukkan bahwa sepanjang masa perjuangan pengembangan lembaga pendidikan Muhammadiyah dari tahun 1952-2014, Muhammadiyah Sumbawa mampu memberi peranan penting dalam mengembangan lembaga pendidikan Muhammadiyah Sumbawa dengan memberi pedoman keislaman, yang mana diwujudkan melalui tiga jalur pendidikan, yaitu pendidikan formal, nonformal dan informal. Adapun faktor pendukung dan penghambat yang sangat mempengaruhi keberhasilan organisasi Muhammadiyah Sumbawa dalam mengembangkan lembaga pendidikan Muhammadiyah dapat dilihat dari beberapa faktor internal dan eksternal adalah sekolah, SDM, dan alat pendidikan. Sedangkan faktor penghambat yang paling pokok adalah faktor dana yang merupakan aset berjalannya suatu pendidikan, dan tersaingi ketat oleh lembaga pendidikan negeri.

Kata Kunci: Sejarah dan perkembangan lembaga pendidikan Muhammadiyah

\section{PENDAHULUAN}

Muhammadiyah adalah nama gerakan Islam yang lahir di Kauman Yogyakarta pada tanggal 18 November 1912. Pendiri Muhammadiyah adalah seorang kyai yang dikenal alim, cerdas, dan berjiwa pembaharu, yakni Kyai Haji Ahmad Dahlan, yang sebelumnya atau nama kecilnya bernama Muhammad Darwis. Muhammadiyah didirikan dalam bentuk organisasi atau perkumpulan atau perhimpunan resmi, yang sering disebut dengan "persyarikatan", yang waktu itu memakai istilah "persjarikatan Moehammadijah"1.

Muhammadiyah telah mengadakan pembaharuan pendidikan agama dengan jalan modernisasi dalam sistem pendidikan yang disesuaikan dengan tuntutan dan kehendak zaman. Muhammadiyah mendirikan sekolah-sekolah umum, memiliki ciri khusus keagamaan, dari taman kanak-kanak hingga perguruan tinggi. Mengajarkan agama dengan cara yang mudah difahami, didaktis dan pedagogis, selalu menjadi pemikiran Muhammadiyah. Maka dalam pembaharuan pendidikan ini, warga Muhammadiyah harus mempunyai etos kerja Islami, seperti: kerja keras, disiplin, tidak menyia-nyiakan waktu, berusaha secara maksimal/optimal untuk mencapai suatu tujuan. Hal ini sesuai dengan tujuan penciptaan manusia yang ditegaskan dalam Surat Ali Imran: 142.

1 Haedar Nashir, Muhammadiyah Gerakan Pembaharuan, (Yogyakara: Suara Muhammadiyah, 2010), hlm. 15.
Apakah kamu mengira bahwa kamu akan masuk surga, padahal belum nyata bagi Allah orang-orang yang berjihad diantaramu dan belum nyata orang-orang yang saba $r$.

Dalam perkembangannya, Muhammadiyah dari waktu ke waktu terus meningkatkan peran dan memperluas kerja dalam peningkatan dan kemajuan pendidikan Islam di Indonesia. Hasil yang sangat nyata adalah wujud amal usaha yang terdiri atas ribuan sekolah mulai dari Taman Kanak-kanak hingga Perguruan Tinggi, rumah sakit, balai bersalin, panti asuhan, panti jompo, rumah-rumah sosial, dan lembaga ekonomi.

Muhammadiyah juga merupakan sebuah organisasi dakwah Islam amar makruf nahi munkar. "Dakwah dilakukan melalui penyelenggaraan berbagai bentuk pelayanan yang diberikan kepada masyarakat, antara lain di bidang kesehatan, pendidikan, bidang sosial lainnya, dan bidang pelayanan keagamaan langsung". Pelayanan keagamaan langsung yang dimaksud di sini adalah kegiatan seperti pengajian, khutbah, tabligh akbar, dan dakwah khusus di masyarakat terasing.

Adapun perkembangan gerakan dakwah Lembaga Pendidikan Muhammadiyah Sumbawa Nusa Tenggara Barat telah dapat dirasakan oleh masyarakat, khususnya masyarakat Sumbawa. Kehadiran Muhammadiyah Sumbawa telah terlihat dengan banyaknya perkembangan amal usaha yang telah dilakukan, berupa:

2 Al-Qur'an dan Terjemahan, Edisi Departemen Agama, (Jakarta: Riels Grafika, 2009), hlm. 112. 
Pendidikan Prasekolah, Pendidikan Dasar, Pendidikan Menengah, Pendidikan Tinggi, dan Panti Asuhan. Sambutan yang baik dari masyarakat terhadap kegiatan-kegiatan pengajian yang diselenggarakan Pimpinan Daerah Muhammadiyah Sumbawa menjadikan maraknya pengamalan ibadah serta semangat menuntut ilmu agama bagi masyarakat Sumbawa. Hal itu terlihat dari antusiasnya masyarakat dalam mengikuti kegiatan-kegiatan Muhammadiyah Sumbawa khususnya kegiatan bidang tarjih, tajdid dan tabligh. Di samping itu, kegiatan-kegiatan pendidikan Islam yang diselenggarakan oleh Lembaga Pendidikan Muhammadiyah Sumbawa juga merupakan kegiatan untuk warga Muhammadiyah dan masyarakat simpatisan Kabupaten Sumbawa.

Berdasarkan pada paparan di atas, penulis tertarik untuk melakukan penelitian lebih lanjut di Lembaga Pendidikan Muhammadiyah Sumbawa, dengan judul: Sejarah dan Perkembangan Lembaga Pendidikan Muhammadiyah di Kabupaten Sumbawa Nusa Tenggara Barat Tahun 1940-2014.

\section{METODE PENELITIAN}

\section{Jenis dan Pendekatan Penelitian}

Jenis penelitian ini adalah penelitian lapangan (field research), yaitu "penelitian yang pengumpulan datanya dilakukan di lapangan, seperti lingkungan masyarakat, lembaga-lembaga, dan organisasi kemasyarakatan. Atau dapat diartikan penelitian dengan jalan terjun langsung ke tempat penelitian untuk mengamati dan terlibat langsung dengan objek penelitian"3.

Adapun pendekatan yang digunakan adalah pendekatan sosiologis dan historis. Menurut Abuddin Nata menjelaskan bahwa sosiologi itu adalah ilmu yang mempelajari hidup bersama dalam masyarakat dan menyelidiki ikatan-ikatan antara manusia yang menguasai hidupnya itu ${ }^{4}$. Sedangkan historis menurut Navis dalam Andi Prastowo $^{5}$, sejarah adalah deskripsi yang

3 Lexy J Moleong, Metodologi Pendidikan Kualitatif, (Bandung: Remaja Rosdakarya, 2007), hlm. 4.

4 Abuddin Nata, Metodologi Studi Islam, (Jakarta: Rajawali Pers, 2009), hlm. 38.

5 Andi Prastowo, Memahami Metode-Metode Penelitian, terpadu dari keadaan-keadaan atau faktafakta masa lampau yang ditulis berdasarkan penelitian serta studi kritis untuk mencari kebenaranSubyek Penelitian

\section{Sumber Data}

Sumber data dalam penelitian adalah subjek dari mana data dapat diperoleh. Untuk memperjelas subjek penelitian, maka penulis kemukakan bahwa data diperoleh dari pengurus Pimipinan Daerah Muhammadiyah Sumbawa, di antaranya yaitu: H. Naziruddin Lambaji, selaku Ketua Pimpinan Daerah Muhammadiyah Sumbawa, Faishal Salim, selaku Sekretaris Pimpinan Daerah Muhammadiyah Sumbawa, Baharuddin, selaku Ketua Majelis Dikdasmen, dan Ahmad Jama'an MY., selaku Ketua Majelis Tarjih dan Tabligh.

\section{Metode Pengumpulan Data}

Dalam rangka memperoleh data yang akurat, maka penulis menggunakan metode pengumpulan data sebagai berikut:

\section{a. Metode wawancara (interview)}

Metode wawancara (interview) adalah "metode pengumpulan data dengan cara tanya jawab sepihak oleh pewawancara (pengumpul data) kepada responden yang dikerjakan dengan sistematis dan berlandaskan tujuan penelitian" ${ }^{\prime 6}$. Metode ini penulis gunakan untuk memperoleh data tentang sejarah perkembangan Lembaga Pendidikan Muhammadiyah di Kabupaten Sumbawa dalam upaya meningkatkan kualitas pendidikan Islam di Kabupaten Sumbawa.

\section{b. Metode Dokumentasi}

Metode dokumentasi adalah "mencari data mengenai hal-hal atau variabel yang berupa catatan, transkrip, buku, surat kabar, majalah, agenda, dan sebagainya"7. Metode dokumentasi ini digunakan untuk memperoleh data-data yang berkaitan dengan

(Jogjakarta: Ar-Ruzz Media, 2011), hlm. 33

6 Sutrisno Hadi, Metodologi Research, (Yogyakarta: Fakultas Psikologi UGM, 2007), hlm: 218.

7 Suharsimi Arikunto, Prosedur Penelitian Suatu Pendekatan Praktek, (Jakarta: Rineka Cipta, 2006), hlm. 126. 
dokumen-dokumen atau arsip-arsip yang didapatkan dalam penelitian, yaitu buku sejarah pergerakan Muhammadiyah Sumbawa, struktur personalia pimpinan, kegiatankegiatan, dan data-data lain yang berhubungan dengan Muhammadiyah di Kabupaten Sumbawa.

\section{c. Metode observasi (pengamatan)}

Teknik observasi yang penulis gunakan adalah observasi langsung, artinya penulis terjun langsung dengan mengadakan pengamatan dan pencatatan di Pimpinan Daerah Muhammadiya Sumbawa untuk mendapatkan data. Metode ini digunakan untuk mendapatkan data letak geografis, sarana dan prasarana atau fasilitas dalam sejarah perkembangan Lembaga Pendidikan Muhammadiyah di Kabupaten Sumbawa.

\section{Metode Analisis Data}

Apabila data telah terkumpul, maka langkah selanjutnya adalah menganalisis data, yaitu pengolahan data untuk menarik kesimpulan . Dalam hal ini penulis menggunakan teknik analisis deskriptif kualitatif, yaitu menggambarkan fenomenafenomena yang ada pada saat ini atau yang saat lampau, dari seluruh data hasil observasi, wawancara dan dokumentasi ${ }^{8}$. Penelitian ini menggambarkan suatu kondisi apa adanya berdasarkan data yang diperoleh tanpa adanya manipulasi atau pengubahan data, dengan tahapan analisis, pertama, data yang telah diperoleh, dipilih atau direduksi (penggolongan data serta membuang yang tidah perlu); kedua, menyajikan data yang telah direduksi tersebut dalam bentuk narasi; dan yang terakhir adalah penarikan kesimpulan dari data yang telah dipaparkan.

8 Nana Syaodih Sukmadidata, Metode Penelitian Pendidikan, (Bandung: Remaja Rosdakarya, 2010), hlm. 54.

\section{HASIL DAN PEMBAHASAN}

\section{Sejarah dan Latar Belakang Berdirinya Muhammadiyah di Kabupaten Sumbawa}

Muhammadiyah adalah sebuah organisasi Islam yang besar di Indonesia. Nama organisasi ini diambil dari nama Nabi Muhammad Shalallahu 'Alaihi Wasallam, sehingga Muhammadiyah juga dapat dikenal sebagai orang-orang yang menjadi pengikut Nabi Muhammad Shalallahu 'Alaihi Wasallam.

Berdirinya Muhammadiyah di Kabupaten Sumbawa Pada tanggal 6 Mei 1940, dilayangkanlah sepucuk surat yang ditujukan kepada Hoofdbestur (Pimpinan Pusat) Muhammadiyah di Yogyakarta yang isinya memohon agar Pimpinan Pusat dapat mengesahkan berdirinya Group Muhammadiyah di Sumbawa Besar. Tidak lama kemudian, yakni pada tanggal 22 Rabi'ul Akhir $1359 \mathrm{H}$, bertepatan dengan tanggal 29 Mei 1940, terbitlah Surat Ketetapan Pimpinan Pusat Muhammadiyah yang isinya menetapkan dan mengakui secara syah berdirinya Group Muhammadiyah di Sumbawa Besar dan dipimpin oleh Abdullah Nur, tokoh yang pendiam dan bukanlah seorang pembicara yang lancar apalagi seorang ulama yang fasih dalam agama. Tetapi pembawaan dan sikapnya beliau yang penuh kewibawaan, pengertian serta istiqomah beliau dalam agama, sehingga dari itu beliau didukung sangat cocok untuk memimpin cabang Muhammadiyah pertama di Kabupaten Sumbawa9.

Abdullah Nur yang dilahirkan di pada tanggal 2 Maret 1899 di Taliwang Sumbawa Besar (sekarng telah menjadi Kabupaten Sumbawa Barat) dan istri beliau bernama Sitti Asma. Dan beliau meninggal dunia di Jakarta pada tanggal 6 Nopember 1969, setelah mengabdikan

9 Buku Sejarah Pergerakan Muhammadiyah di Sumbawa yang ditulis oleh A. Latief Malik, dikutip pada tanggal 15 April 2015. 
hampir seluruh hidupnya bagi kemajuan dan perkembangan Islam di Sumbawa dan sehingga beliau hampir diedintik dengan Muhammadiyah Sumbawa.

Selepas tamat dari sekolah rakyat pada tahun 1916, Abdullah Nur diterima bekerja di kantor Proefstation (Departemen) Pertanian di Sumbawa Besar. Karena dengan ketekunan dan kemampuan, beliau pada saat itu baru berumur 17 tahun kemudian dikirim ke Bogor (Jawa Barat) untuk mengikuti Kursus Latihan Pertanian.

Sejak itulah Abdullah Nur berkenalan dengan buku-buku bacaan yang bernapaskan Islam dan mendalaminya. Dan setelah selesai mengikuti kursus, dan balik ke Sumbawa beliau tidak ada kata patah semangat yang walaupun jauh dari kota tempat beliau mudah mendapatkan buku-buku keislaman. Karena dengan semangat dan giat membaca, beliau mendatangkan buku-buku keislaman sehingga berlangganan majalah-majalah Islam yang ada di Jawa.

Sebelum dipertemukan dengan Muhammadiyah, pada tahun 1934 Abdullah Nur sempat mendirikan sebuah organisasi keagamaan yang diberi nama Majelis Ahlus Sunnah Asli (MASA). Setelah dipertemukan dengan organisasi Muhammadiyah tahun 1940, dan beliau beserta kawankawannya di MASA sepakat mendirikan Muhammadiyah di Sumbawa dan secara keseluruhan warga MASA ikut bergabung ke dalam Muhammadiyah. Abdullah Nur mendirikan organisasi MASA atau Groep Muhammadiyah Sumbawa berdasarkan pada dua faktor yang melatarbelakanginya, yaitu faktor subjektif dan objektif. Faktor pertama berkait langsung dengan perjalanan biografi pribadi Abdullah Nur, sedangkan faktor kedua berkait dengan kondisi internal dan eksternal umat Islam di Kabupaten Sumbawa. Kondisi internal berkaitan dengan implemintasi Islam di Sumbawa, sedangkan kondisi eksternal berkaitan dengan pengaruh-pengaruh asing. Berikut latar belakang berdirinya Muhammadiyah di Kabupaten Sumbawa, yaitu:

1) Faktor subjektif
a) Memperbanyak
membaca buku-buku keislaman dan

mendalaminya.

b) Memurnikan ajaran Islam dan kembali kepada ajaran Al-Qur'an dan Hadist yang shohih

c) Mengamalkan ajaran Islam ke orang-orang terdekat dan melalui majelis ta'lim atau pengajian dari rumah ke rumah.

d) Ajaran Islam di Sumbawa harus diselamatkan dari kotorankotoran bid'ah dan khurafat yang sangat bertentangan dengan ajaran serta tuntutan Rasulullah Shalallahu 'Alaihi Wasallam ${ }^{10}$.

2) Faktor objektif ${ }^{11}$

a) Kebanyakan masyarakat mengiringi jenazah ke kuburan dengan mengucapkan zikir dan tahlilan dengan suara yang nyaring.

b) Adanyakuburan HabibdiLabuhan Sumbawa yang dianggap sangat keramat, sehingga dijadikan tempat meminta-minta, dengan syarat harus membawa seekor ayam dan selapis kain putih.

c) Adanya sumur Paying (nama sebuah tempat dan dijadikan nama sumur) di Labuhan Puntik yang diziarahi dan dikeramatkan.

d) Setiap malam Jum'at masyarakat membakar kemenyan, lalu setiap sudut rumah diasapi.

e) Apabila ada usungan (orang yang mengiringi dan menggotong jenazah dengan keranda ke kuburan) jenazah melewati depan rumah, para ibu-ibu melemparkan bara api dan segayung air ke halaman rumah.

f) Perayaan Maulid Nabi dirayakan dengan pembuatan aneka makanan dan juadah (sebuah tempat kue yang dihias dengan ikon Sumbawa) diarak ke masjid sebelum dibagi-bagikan kepada petinggi negeri, suatu cara yang tidak pernah dicontohkan oleh sahabat-sahabat Rasulullah Shalallahu 'Alaihi Wa Sallam. 
g) Adanya acara tahlilan di rumah orang yang kematian dan $p$ gantantangan yang dialaminya. Maka dari itu, justru menjadi perhatian serius dalam mengembangkan lembaga pendidikan Muhammadiyah di Sumbawa. Oleh karena itu, organiasi Muhammadiyah Sumbawa mampu mengembangkan dan mendirikan beberapa amal usaha, khususnya pada lembaga pendidikan mulai dari pendidikan formal, nonformal dan informal.

Perjalanan perkembangan lembaga pendidikan Muhammadiyah Sumbawa dari tahun ke tahun atau dari perode 1-9 pimpinan daerah Muhammadiyah Sumbawa telah mampu mendirikan lembaga pendidikan sebanyak 22 lembaga, yang mana mulai perintisan ini pada tahun 1940-1952 dan masa pengembangan tahun 1952-2014. Dan di antaranya ada beberapa jumlah sekolah yang berkembang sebanyak 16 sekolah dan ada yang stagnan sebanyak 5 sekolah dan 1 sekolah tinggi (kerjasama dengan UMM Mataram NTB). Demikian data perkembangan lembaga pendidikan formal Muhammadiyah Sumbawa tahun 1940-2014', yaitu:

12 Wawancara bersama bapak Baharuddin, selaku Ketua Majlis Dikdasmen PDM Kabupaten Sumbawa, pada tanggal 30 Maret 2015, jam 12:30 di rumahnya.

Tabel II

\begin{tabular}{|c|c|c|c|c|}
\hline No & Pimpinan Daerah & $\begin{array}{l}\text { Jenjang } \\
\text { Pendidikan }\end{array}$ & Perkembangan & Keterangan \\
\hline \multirow[b]{2}{*}{1.} & & $\mathrm{SD} / \mathrm{MI}$ & Stagnan & $\begin{array}{l}1 \text { sekolah berkembang dan diminati oleh } \\
\text { masyarakat. } \\
\text { Dan } 2 \text { sekolah tidak terkomendasi dan tutup. }\end{array}$ \\
\hline & $\begin{array}{l}\text { Abdullah Nur } \\
\text { Periode } \\
\text { 1940-1966 }\end{array}$ & SMP/MTS & Stagnan & $\begin{array}{l}3 \text { sekolah mengalami keterpurukan di masa } \\
\text { penjajahan hingga terjadi penutupan. Dan } \\
\text { murid beralih ke sekolah pemerintahan/ } \\
\text { negeri. }\end{array}$ \\
\hline 2. & $\begin{array}{l}\text { Usman Sidik } \\
\text { Periode } \\
1966-1972\end{array}$ & - & - & $\begin{array}{l}\text { Mengembangkan sekolah yang didirikan } \\
\text { oleh masa periode pertama. }\end{array}$ \\
\hline \multirow{3}{*}{3.} & & SMP/MTS & Berkembang & \multirow{3}{*}{$\begin{array}{l}\text { Pada periode ke3 ini mendirikan } 3 \text { jenjang } \\
\text { sekolah dan mengalami kemajuan, dan terus } \\
\text { berkembang hingga sekarang dan didukung } \\
\text { penuh oleh masyarakat. }\end{array}$} \\
\hline & $\begin{array}{l}\text { H.L.A.Zainuddin } \\
\text { Periode } \\
\text { 1972-1977 }\end{array}$ & SMA & Berkembang & \\
\hline & & $\mathrm{SD} / \mathrm{MI}$ & Berkembang & \\
\hline 4. & $\begin{array}{c}\text { Chairuddin } \\
\text { Nurdin, BA. } \\
\\
\text { Periode } \\
1977-1982 \\
\end{array}$ & - & - & $\begin{array}{l}\text { Menindak lanjuti pengembangan dan } \\
\text { pengelolahan sekolah-sekolah yang telah } \\
\text { didirikan oleh masa periode sebelumnya }\end{array}$ \\
\hline
\end{tabular}




\section{No Pimpinan Daerah $\begin{gathered}\text { Jenjang } \\ \text { Pendidikan }\end{gathered}$ Perkembangan Keterangan}

H.M. Imran TK Berkembang

5.

$$
\text { Periode }
$$

1982-1987

\begin{tabular}{|c|c|c|}
\hline 1982-1987 & SMA/MA & Berkembang \\
\hline \multirow{4}{*}{$\begin{array}{c}\text { Chairuddin } \\
\text { Nurdin, BA. } \\
1987-1992\end{array}$} & TK & Berkembang \\
\hline & MI/SD & Berkembang \\
\hline & SMP & Berkembang \\
\hline & SMA & Berkembang \\
\hline
\end{tabular}

H. Suharli

Anggaimarji

7.

Periode

1992-2005
TK Berkembang
Pada periode ke5 ini mendirikan 2 jenjang sekolah dan mengalami kemajuan, dan terus berkembang hingga sekarang dan didukung penuh oleh masyarakat.

Pada periode ke6 ini mendirikan 4 jenjang sekolah dan mengalami kemajuan, dan terus berkembang hingga sekarang dan didukung penuh oleh masyarakat di samping sekolah negeri.

Pada periode ke7 ini mendirikan 1 tambahan jenjang sekolah taman kanak, kerjasama dengan Ortum Aisyiah dan TK ini mengalami kemajuan, dan terus berkembang dengan jumlah murid yang sangat signifikan hingga sekarang dan didukung penuh oleh masyarakat setempat.

MTS Berkembang

SMP BS Berkembang

\section{H. Zainal Arifin,}

8. S.Pd.

Periode

2005-2010

ST

(kerjasama

dgn UMM

Mataram)

9. Drs. H. Naziruddin 2010-2015
SMA M
Muhammadiyah di Kec. Maronge berkembang karena memiliki potensi yang baik sehingga ada peningkatan jumlah murid dan atas dukungan besar masyarakat setempat.

Perkembangan SMK Muhammadiyah di Kab. Sumbawa mengalami stagnan, karena terjadi persaingan dengan sekolah SMK Negeri yang ada di Kab. Sumbawa sehingga mengalami penurunan jumlah murid dan masyarakt lebih condong pada sekolah negeri.

Perguruan Tinggi (kerjasama dengan UMM Mataram) di Kab. Sumbawa mengalami stagnan, karena Peraturan Dinas Perguruan Tinggi meniadakan dan mencabut MoU tiap Perguruan tinggi yang membuka cabang di tiap daerah, maka harus ditutup.

berkembang, karena memiliki potensi yang baik sehingga ada peningkatan jumlah murid dan atas dukungan besar masyarakat setempat.
Adapun selain mengembangkan lembaga pendidikan formal, Muhammadiyah Sumbawa mampu mendirikan lembaga pendidikan nonformal, dilakukan sebagai bentuk kegiatan sosial kemasyarakatan, yaitu: 1) Mengelola Panti Asuhan, sebagai upaya untuk membina anak yatim piatu serta dari anak masyarakat bawah yang kurang mampu ke dalam pendidikan Islam formal 
maupun nonformal; 2) Mengelola Pondok Pesantren Tahfiz Al-Qur'an. Menjadikan lembaga unggul yang mampu mencetak kader penerus Islam yang berilmu dan berpengetahuan, berakhlak mulia, berprestasi dan bermanfaat bagi agama dan negara; 3) Mengelola masjid, menjadikan masjid sebagai basis pembinaan umat/ jamaah. Dan adapun dalam pendidikan nonformal meliputi dari beberapa kegiatan yang dilaksankan oleh beberapa Majelis Pimpinan Daerah Muhammadiyah Sumbawa NTB.

\section{Faktor pendukung dan penghambat}

Dalam melaksanakan pengembangan lembaga pendidikan Muhammadiyah banyak mendapat dukungan dan hambatan dari kepengurusan dan masyarakat. Faktorfaktor pendukung dan penghambat tersebut sebagai berikut:

1) Faktor-faktor pendukung:

Dalam perkembangan lembaga pendidikan Muhammadiyah di Sumbawa terdapat faktor pendukung bagi organisasi Muhammadiyah Sumbawa, baik dalam internal maupun ekternal di antaranya adalah faktor kepengurusan Muhammadiyah, sekolah, masyarakat dan alat pendidikan.

2) Faktor penghambat:

Sepanjang dalamsejarah perkembangan lembaga pendidikan Muhammadiyah di Sumbawa tak pernah lepas dari dua faktor penghambat yaitu faktor internal, terjadi dalam kepengurusan, pendidik, manajemen pengolahan lembaga pendidikan dan dana. Dan yang kedua faktor eksternal yaitu terjadi pada lembaga pendidikan masih tersaingi oleh lembaga pendidikan negeri, dan masyarakat masih belum sepenuhnya menilai lembagalembaga pendidikan Muhammadiyah Sumbawa sebagai sekolah swasta yang mempunyai integritas yang unggul sehingga dijadikan sebagai lembaga pendidikan nomor dua setelah sekolahsekolah negeri yang ada di Kabupaten Sumbawa.

\section{PENUTUP}

Dengan senantiasa memohon pertolongan dan kekuatan dari Allah Subhaanahu wa ta'ala, penulis panjatkan rasa syukur kepada Allah 'azza wa jalla yang senantiasa telah melimpahkan rahmat, nikmat Islam dan Iman, kesehatan dan kekuatan sehingga mampu menyelesaikan tesis yang berjudul Sejarah dan Perkembangan Lembaga Pendidikan Muhammadiyah di Kabupaten Sumbawa Nusa Tenggara Barat Tahun 1940-2014.

Penulis menyadari dengan segala kerendahan hati atas keterbatas pengetahuan yang penulis miliki, sehingga dalam penulisan tesis ini masih terdapat kekurangan. Oleh karena itu, dengan rendah hati penulis menerima saran dan masukan yang bersifat membangun demi kepuasan dan kemajuan dalam penyusunan tesis ini.

Semoga dengan kelancaran penyusunan tesis ini dapat menambah pengetahuan dan bermanfaat bagi pembaca pada umumnya dan penulis sendiri pada khususnya. Sekian, semoga Allah subhaanahu wa ta'ala dapat meridhoihi kita semua ke jalan yang lurus. Amin ya rabbal alamiin.

\section{DAFTAR PUSTAKA}

Al-Qur'an dan Terjemahan. Edisi Departemen Agama. 2009. Jakarta: Riels Grafika.

Arikunto, Suharsimi. 2006. Prosedur Penelitian Suatu Pendekatan Praktek. Jakarta: Rineka Cipta.

Hadi, Sutrisno. 2007. Metodologi Research. Yogyakarta: Fakultas Psikologi UGM.

Malik, Abdul Latief. 2005. Sejarah Pergerakan Muhammadiyah di Sumbawa. Surabaya: Rinta.

Moleong, Lexy J. 2007. Metodologi Pendidikan Kualitatif. Bandung: Remaja Rosdakarya.

Nashir, Haedar. 2010. Muhammadiyah Gerakan Pembaharuan. Yogyakara: Suara Muhammadiyah 
PROFETIKA, Jurnal Studi Islam, Vol. 18, No. 1, Juni 2017: 18-26

Nata, Abuddin. 2009. Metodologi Studi Islam. Jakarta: Rajawali Pers

Prastowo, Andi. 2011. Memahami Metode-Metode Penelitian. Jogjakarta: Ar-Ruzz Media.

Sukmadidata, Nana Syaodih. 2010. Metode Penelitian Pendidikan. Bandung: Remaja Rosdakarya

Zuhairini. 2008. Filsafat Pendidikan Islam. Jakarta: Bina Aksara. 